\title{
Psychosocial Adjustment among Orphan Children Living with HIV/AIDS
}

\author{
Sampathkumar ${ }^{1}$, Ravikumar, M. B. ${ }^{2 *}$, Manjunatha, ${ }^{3}{ }^{3}$, Surma, S. ${ }^{3}$
}

\section{ABSTRACT}

AIDS is the final stage of infection with the retro-virus HIV. This disease not only affects the individuals' physical health, but it also affects the psychological health and the adjustment of an individual towards oneself and his surrounding environment. The objective of the present study is to understand the level of psychosocial adjustment among orphan and non-orphan children living with HIV/AIDS. Adjustment inventory was administered to 400 orphan and non-orphan children living with HIV/AIDS. Results indicated that orphan children with HIV/AIDS were having lower level of adjustment than non-orphan children with HIV/AIDS. Within the orphan children with HIV/AIDS the girl and rural children were having lower level adjustment compared to the boy and urban children. The study suggested the need for specific interventions to improve adjustment of the orphan children with HIV/AIDS.

Keywords: Adjustment, Orphan HIV/AIDS children, HIV/AIDS Children.

An orphan child is defined as a person who has lost one or both parents (United Nations Children Education Fund (UNICEF), 2004). The death of a parent during childhood is traumatic, with a profound and potentially lasting impact on a child's psychosocial wellbeing (Li et al., 2008). In addition to the developmental vulnerability normally faced by any child whose parents have died, experience with parental illness and death due to Acquired Immune-Deficiency Syndrome (AIDS) may create additional cognitive and social challenges. These challenges may further aggravate the grieving process among children who have lost parents or who face the potential of losing parents to AIDS, and may increase risk for psychosocial adjustment problems.

The Human Immunodeficiency Virus (HIV) and AIDS researchers have projected an estimated 65 million deaths from AIDS by the year 2020; more than triple the number who died in the first 20 years of the epidemic unless major efforts are put toward primary prevention or major

\footnotetext{
${ }^{1}$ Assistant Professor, Department of Studies in Psychology, University of Mysore, Mysuru -570 006, Karnataka, India.

${ }^{2}$ Counsellor, ART Centre, Mandya Institute of Medical Sciences, Mandya, Karnataka, India.

${ }^{3}$ Assistant Professor, Department of Studies in Psychology, Karnataka State Open University, Mysuru -570 006 , Karnataka, India.

*Responding Author

(C) 2015 I Sampathkumar, Ravikumar, Manjunatha, Surma; licensee IJIP. This is an Open Access Research distributed under the terms of the Creative Commons Attribution License (http://creativecommons.org/licenses/by/2.0), which permits unrestricted use, distribution, and reproduction in any Medium, provided the original work is properly cited.
} 
developments in treatment take place (Altman, 2002). According to National Aids Control Organization (NACO) report 2009-10, India has 2.27 million HIV-infected persons, the third highest in the world after South Africa and Nigeria. The Karnataka State Aids Prevention Society's (KSAPS) Consolidated ART report July 2012, the scenario of Karnataka state is 0.223 million adult and 0.016 million children are registered for Anti Retroviral Therapy (ART).

AIDS is the final stage of infection with the retro-virus HIV. This virus gradually impairs the immune system which is crucial for the suppression of infections, viruses and bacteria. As the immune systems weakens, HIV infected person becomes infected with opportunistic infections. HIV/AIDS is a chronic disease and without treatment persons will eventually die. According to Tate et al. (2003), the new advances for treatment of HIV using Highly Active Antiretroviral Therapy (HAART) have dramatically improved disease prognosis.

Antiretroviral therapy (ART) in children preserves or restores immune function; provides sustained suppression of the viral load; promotes or restores normal growth and development; improves the quality of life; prevents complicating infections and cancers; and prolongs the child's life. Yet an outright cure remains elusive, leaving persons with the challenges of living with a chronic medical condition. Orphan children with HIV positive can live a longer life because of medical advances like ART, but treatment programs have not been able to eradicate the virus and cure the disease. As a result, orphan children are living longer with a chronic condition that continuously presents physical, psychological and social challenges. Like all patients with chronic medical disorders, HIV-infected children also are at increased risk for specific psychiatric and psycho-social adjustment problems.

\section{Adjustment}

The term adjustment is often used as a synonym for accommodation and adaptation. Strictly speaking, the term denotes that the results of equilibrium, which may be affected by either of these processes (Monroe, 1990). It is used to emphasize the individual's struggle to get along or survive in his or her social and physical environment. Several factors are thought to influence the psychosocial adjustment of orphan children born with HIV infection.

These factors include (a) the presence of HIV in the central nervous system during fetal development and throughout childhood, (b) co-occurring medical conditions and complications of HIV disease, including body image issues, (c) teratogenic effects of drug and alcohol during the prenatal period, (d) cognitive and neurological deficits, (e) other psychosocial factors (maternal illness, multiple separations, transitions, and losses), (f) whether the child knows his or her HIV status and (g) environmental factors (Brown et al., 2000; Gaughan et al., 2004; Lwin and Melvin, 2001; Mellins et al., 2003). Environmental factors affecting families living with HIV include poverty, violence, racism, overcrowding, single-parent households (Armistead and Forehand, 1995). Such factors also would likely increase the risk of psycho-social adjustmental problems in orphan children living with HIV/AIDS. 


\section{Psychosocial Adjustment among Orphan Children Living with HIV/AIDS}

Orphan children living with HIV/AIDS are considered as highly deprived class of society. These children are left helpless, abandoned, neglected by the parents/ caregivers due to social, economic and personal reasons like gender, domicile, age, etc. They are deprived of one or more necessities of life. Early separation from parents, deprivation of parental care, love, affection, warmth, security, acceptance and discipline during childhood disrupts their normal educational development resulting in adjustmental problems. Makame, Ani and McGregor (2002) found that orphans had increased internalizing problems compared with non-orphans. In Ethiopia, Bhargava (2005) found that Children orphaned by AIDS showed more emotional and social adjustment problems, and girls reported higher levels of difficulties than boys. Atwine et al. (2005) found that rural orphans were more likely to be anxious, depressed and to display anger, showed significantly higher scores for feelings of hopelessness and suicidal ideation.

A study in Uganda had observed also girls with HIV/AIDS have lower education adjustment, knowledge, self-confidence and self-esteem (FAWE, 2000). However, it was also observed that school drop-out rates were higher among females students (7.6\%) compared to males (6\%) in Uganda (Baguma and Muhanguzi, 2000). Most of the reasons for female school dropout were due to family socio-cultural reasons including illness of parents due to HIV/AIDS or orphan hood due to HIV/AIDS or other causes (Baguma and Muhanguzi, 2000). Other sociocultural reasons included the gender inequality accorded to girls (Uganda Bureau of statistics, 2006). Boys were generally provided with the opportunities to continue with their education uninterrupted, while girls were usually requested by their families to stay at home to continue providing household services in the event of illnesses or demise of their parents (Baguma and Muhanguzi, 2000; Uganda Bureau of Statistics, 2006). It should be noted here that, orphan hood due to HIV/AIDS has been one of the greatest effects of HIV/AIDS on school girls' education in Africa leading to school absenteeism during their parents' illnesses and emotional stress manifested in inappropriate behavior (Baggaley and Needham, 1997; Yun, 2001; Wahl, 2001). Therefore, based on these supporting findings, it can be said that the emotional support within the fostering family will play a crucial role in the development of children.

So it becomes necessary to know whether HIV infected children who are devoid of family life with the emotional warmth grow up normally? How well they are able to cope with themselves and adjust to the demands of the environment/society around them? In this context the present study attempts to know the level of psychosocial adjustment of orphan children living with HIV/AIDS. Outcome of investigation will provide the way and need for appropriate counselling, guidance, care and support to overcome their adjustment problems.

\section{OBJECTIVES}

1. To study the level of social, emotional and educational adjustment of the orphan and nonorphan children living with HIV/AIDS.

2. To study the gender differences in social, emotional and educational adjustment of the orphan children living with HIV/AIDS. 


\section{Psychosocial Adjustment among Orphan Children Living with HIV/AIDS}

3. To study the domicile differences in social, emotional and educational adjustment of the orphan children living with HIV/AIDS.

4. To study the interaction effects of gender and domicile on adjustment problems of the orphan children living with HIV/AIDS.

\section{METHOD}

\section{Hypotheses}

$\mathbf{H}_{\mathbf{1}}$ : The orphan children with HIV/AIDS have lower social, emotional and educational adjustment than the non-orphan children with HIV/AIDS.

$\mathbf{H}_{2}$ : The orphan girls with HIV/AIDS have lower social, emotional and educational adjustment than the orphan boys with HIV/AIDS.

$\mathbf{H}_{3}$ : The orphan rural children with HIV/AIDS have lower social, emotional and educational adjustment than the orphan urban children with HIV/AIDS.

$\mathbf{H}_{4}$ : There is an interaction effect between gender and domicile on social, emotional and educational adjustment of the orphan children with HIV/AIDS.

\section{Participants:}

The participant group consists of total 400 children with HIV/AIDS, 200 were orphan and another 200 were non-orphan. Participants were selected from Paediatric ART Centre, Indira Gandhi Institute of child Health (IGICH), Bangalore. The participants' age ranges from 9 to 14 years and the mean age was 11.5 years.

\section{Measure}

Adjustment inventory: Developed by Sinha and Singh (1993) was adopted for this study. It consists of 60 items which measure adjustment in three different areas namely social adjustment, emotional adjustment and educational adjustment with 20 items each. The higher score indicates the lower adjustment. The test-retest reliability for 0.93 and the split-half reliability for 0.95 these values found to be highly significant and satisfactory.

\section{Procedure:}

The Participants were given appropriate instructions and administered the Adjustment Inventory in the group of 10 members. They were also asked to give their socio-demographic details in the prescribed profarma. They have to indicate their responses in the answer sheets given to them. Data collection was done in 40 sessions and a session lasted about 45-60 minutes approximately. The data was scored and statistically analysed by using descriptive statistics, independent t-test and Two-way ANOVA techniques. 


\section{RESULTS AND DISCUSSION}

Table 1: shows the mean, SD and $t$ values for psychosocial adjustment of the orphan and the non-orphan children living with HIV/AIDS.

\begin{tabular}{|l|l|l|l|l|l|l|}
\hline \multirow{2}{*}{ DOMAINS } & $\begin{array}{l}\text { SOURCE } \\
\text { VARIATIONS }\end{array}$ & $\mathbf{N}$ & MEAN & SD & t & P \\
\hline \multirow{2}{*}{ Eocial } & Orphan & 200 & 12.53 & 1.835 & 3.117 & .002 \\
\cline { 2 - 5 } & Non-orphan & 200 & 11.96 & 1.790 & & \\
\hline \multirow{2}{*}{ Educational } & Orphan & 200 & 14.68 & 1.701 & 3.219 & .001 \\
\cline { 2 - 5 } & Non-orphan & 200 & 14.11 & 1.869 & & \\
\cline { 2 - 5 } Total & Orphan & 200 & 13.33 & 1.818 & 4.948 & .001 \\
\cline { 2 - 5 } & Non-orphan & 200 & 12.43 & 1.820 & & \\
\cline { 2 - 5 } & Orphan & 200 & 40.47 & 3.995 & 4.757 & .001 \\
\cline { 2 - 4 } & Non-orphan & 200 & 38.48 & 4.364 & & \\
\hline
\end{tabular}

Table 1: shows the mean SD and t values for psychosocial adjustment of the orphan and the nonorphan children living with HIV/AIDS. On social adjustment the orphan children (Mean=12.53; $\mathrm{SD}=1.835$ ) scored higher than the non-orphan children (Mean=11.96; $\mathrm{SD}=1.790$ ) and t value (3.117; $\mathrm{p}<.002$ ) indicating a high significant difference. The orphan children were having significantly lower adjustment than the non-orphan children in social adjustment. On emotional adjustment the orphan children (Mean=14.68; $\mathrm{SD}=1.701$ ) scored higher than the non-orphan children (Mean=14.11; $\mathrm{SD}=1.869)$ and the t value (3.219; $\mathrm{p}<.001)$ indicating a high significant difference. The orphan children were having significantly lower adjustment than the non-orphan children in emotional adjustment. On educational adjustment the orphan children (Mean=13.33; $\mathrm{SD}=1.818$ ) scored higher than the non-orphan children (Mean=12.43; $\mathrm{SD}=1.820$ ) and the $t$ value (4.948; $\mathrm{p}<.001)$ indicating a high significant difference. The orphan children were having significantly lower adjustment than the non-orphan children in educational adjustment.

On the overall adjustment the orphan children (Mean=40.47; $\mathrm{SD}=3.995$ ) scored higher than the non-orphan children (Mean=38.48; $\mathrm{SD}=4.364$ ) and the t value (4.948; $\mathrm{p}<.001)$ indicating a high significant difference. The orphan children were having significantly lower adjustment than the non-orphan children in overall adjustment. Therefore, the formulated $\mathbf{H}_{\mathbf{1}}$; the orphan children with HIV/AIDS have lower social, emotional and educational adjustment than the non-orphan children with HIV/AIDS, is accepted.

Table 2: shows the mean, SD and F values for Social Adjustment of boys/girls and rural/urban orphan children with HIV/AIDS.

\begin{tabular}{|l|l|l|l|l|l|l|}
\hline VARIABLES & $\begin{array}{l}\text { SOURCE OF } \\
\text { VARIATIONS }\end{array}$ & $\mathbf{N}$ & MEAN & SD & F & p \\
\hline \multirow{2}{*}{ Gender } & Boys & 100 & 12.01 & 1.654 & 18.886 & \multirow{2}{*}{.001} \\
\cline { 2 - 6 } & Girls & 100 & 13.04 & 1.869 & & \\
\hline \multirow{2}{*}{ Domicile } & Rural & 100 & 13.18 & 1.844 & 31.813 & .001 \\
\cline { 2 - 6 } & Urban & 100 & 11.87 & 1.581 & & \\
\hline Interaction & Gender*Domicile & 200 & 12.53 & 1.835 & 15.583 & .001 \\
\hline
\end{tabular}




\section{Psychosocial Adjustment among Orphan Children Living with HIV/AIDS}

Table 2: shows the mean, SD and F values for social adjustment of boys/girls and rural/urban orphan children with HIV/AIDS. On the social adjustment the orphan girls (Mean=13.04; SD= 1.869) scored higher than the orphan boys (Mean=12.01; $\mathrm{SD}=1.654$ ) and the $\mathrm{F}$ value (18.886; $\mathrm{p}<.001$ ) indicating a high significant difference. The orphan girls were significantly lower than the orphan boys in social adjustment. Again on the social adjustment the rural orphan children (Mean=13.18; $\mathrm{SD}=1.844$ ) scored higher than the urban orphan children (Mean=11.87; $\mathrm{SD}=1.581$ ) and the $\mathrm{F}$ value (31.813; $\mathrm{p}<.001)$ indicating a high significant difference. The rural orphan children were significantly lower than the urban orphan children in social adjustment. The interaction effect between gender and domicile on social adjustment $(\mathrm{F}=15.583 ; \mathrm{p}<.001)$ is also found to be highly significant.

Table 3: shows the mean, SD and F values for Emotional Adjustment of boys/girls and rural/urban orphan children with HIV/AIDS.

\begin{tabular}{|l|l|l|l|l|l|l|}
\hline VARIABLES & $\begin{array}{l}\text { SOURCE OF } \\
\text { VARIATIONS }\end{array}$ & $\mathbf{N}$ & MEAN & SD & F & P \\
\hline \multirow{2}{*}{ Gender } & Boys & 100 & 14.07 & 1.754 & 29.008 & .001 \\
\cline { 2 - 6 } & Girls & 100 & 15.29 & 1.409 & & \\
\cline { 1 - 5 } & Rural & 100 & 14.97 & 1.749 & 5.715 & .018 \\
\cline { 2 - 5 } & Urban & 100 & 14.39 & 1.607 & & \\
\hline
\end{tabular}

Table 3: shows the mean SD and F values for emotional adjustment of boys/girls and rural/urban orphan children with HIV/AIDS. On the emotional adjustment the orphan girls (Mean=15.29; $\mathrm{SD}=1.409$ ) scored higher than the orphan boys (Mean=14.07; $\mathrm{SD}=1.754$ ) and the $\mathrm{F}$ value (29.008; $\mathrm{p}<.001$ ) indicating a high significant difference. The orphan girls were significantly lower than the orphan boys in emotional adjustment. On the emotional adjustment the rural orphan children (Mean=14.97; $\mathrm{SD}=1.749$ ) scored higher than the urban orphan children (Mean=14.39; $\mathrm{SD}=1.607$ ) and the $\mathrm{F}$ value $(5.715 ; \mathrm{p}<.018)$ indicating a high significant difference. The rural orphan children were significantly lower than the urban orphan children in emotional adjustment. The interaction effect between gender and domicile on emotional adjustment $(\mathrm{F}=.931 ; \mathrm{p}<.336)$ is found non-significant.

Table 4: shows the mean, SD and $F$ values for educational adjustment of boys/girls and rural/urban orphan children with HIV/AIDS.

\begin{tabular}{|l|l|l|l|l|l|l|}
\hline VARIABLES & $\begin{array}{l}\text { SOURCE } \\
\text { VARIATIONS }\end{array}$ & OF N & MEAN & SD & F & P \\
\hline \multirow{2}{*}{ Gender } & Boys & 100 & 13.26 & 1.685 & .153 & .696 \\
\cline { 2 - 6 } & Girls & 100 & 13.39 & 1.948 & & \\
\hline \multirow{2}{*}{ Domicile } & Rural & 100 & 13.78 & 1.967 & 14.313 & .001 \\
\cline { 2 - 5 } & Urban & 100 & 12.87 & 1.535 & & \\
\hline Interaction & Gender*Domicile & 200 & 13.32 & 1.818 & 19.055 & .001 \\
\hline
\end{tabular}




\section{Psychosocial Adjustment among Orphan Children Living with HIV/AIDS}

Table 4: shows the mean SD and F values for educational adjustment of boys/girls and rural/urban of orphan children with HIV/AIDS. On the educational adjustment the orphan girls (Mean=13.39; $\mathrm{SD}=1.948$ ) scored slightly higher than the orphan boys (Mean=13.26; $\mathrm{SD}=1.685$ ) and the $\mathrm{F}$ value (0.153; $\mathrm{p}>.696)$ indicating a non-significant difference. The orphan girls and boys were statistically not having any difference in educational adjustment. On the educational adjustment the rural orphan children (Mean=13.78; $\mathrm{SD}=1.967$ ) scored higher than the urban orphan children (Mean=12.87; SD=1.535) and the F value $(14.313 ; \mathrm{p}<.001)$ indicating a high significant difference. The rural orphan children were significantly lower than the urban orphan children in educational adjustment. The interaction effect between gender and domicile on educational adjustment $(\mathrm{F}=19.055 ; \mathrm{p}<.001)$ were highly significant.

Table 5: shows the mean, SD and F values for Overall Adjustment of boys/girls and rural/urban orphan children with HIV/AIDS.

\begin{tabular}{|c|c|c|c|c|c|c|}
\hline VARIABLES & $\begin{array}{l}\text { SOURCE } \\
\text { VARIATIONS }\end{array}$ & OF $\quad \mathrm{N}$ & MEAN & SD & $\mathbf{F}$ & $\overline{\mathbf{P}}$ \\
\hline \multirow[t]{2}{*}{ Gender } & Boys & 100 & 39.22 & 3.609 & \multirow[t]{2}{*}{23.814} & \multirow[t]{2}{*}{.001} \\
\hline & Girls & 100 & 41.72 & 3.988 & & \\
\hline \multirow[t]{2}{*}{ Domicile } & Rural & 100 & 41.81 & 4.498 & \multirow[t]{2}{*}{27.686} & \multirow[t]{2}{*}{.001} \\
\hline & Urban & 100 & 39.13 & 2.866 & & \\
\hline Interaction & Gender*Domicile & 200 & 40.47 & 3.995 & 14.118 & .001 \\
\hline
\end{tabular}

Table 5: shows the mean SD and F values for overall adjustment of boys/girls and rural/urban orphan children with HIV/AIDS. On the overall adjustment the orphan girls (Mean=41.72; SD= 3.988) scored higher than the orphan boys (Mean=39.22; $\mathrm{SD}=3.609$ ) and the F value (23.814; $\mathrm{p}<.001$ ) indicating a high significant difference. The orphan girls were significantly lower than the orphan boys in overall adjustment. Therefore, the formulated $\mathbf{H}_{\mathbf{2}}$; the orphan girls with HIV/AIDS have lower social, emotional and educational adjustment than the orphan boys with HIV/AIDS, is accepted.

On the overall adjustment of orphan rural children (Mean=41.81; SD=4.498) scored higher than the orphan urban children (Mean=39.13; $\mathrm{SD}=2.866)$ and the $\mathrm{F}$ value $(27.686 ; \mathrm{p}<.001)$ indicating a high significant difference. The orphan rural children were significantly lower than the orphan urban children in overall adjustment. Therefore, the formulated $\mathbf{H}_{\mathbf{3}}$ the orphan rural children with HIV/AIDS have lower social, emotional and educational adjustment than the orphan urban children with HIV/AIDS, is accepted. The interaction effect between gender and domicile on overall adjustment $(\mathrm{F}=14.118 ; \mathrm{p}<.001)$ were highly significant. Therefore, the formulated $\mathbf{H}_{\mathbf{4}}$; there is an interaction effect between gender and domicile on social, emotional and educational adjustment of the orphan children with HIV/AIDS, is accepted.

The overall result indicates that the orphan children have lower social, emotional and educational adjustment than the non-orphan children living with HIV/AIDS. When we consider only orphan 


\section{Psychosocial Adjustment among Orphan Children Living with HIV/AIDS}

children, girl and orphan rural children have lower social and emotional adjustment than their counter parts boy and orphan urban children.

Under the circumstances where the family atmosphere is unhealthy, institutional care is the best available alternative for children living with HIV/AIDS. However a stable, reliable and understanding relationship does not depend primarily on words but on consistent response to child's feelings which gradually develops foundations of trust, confidence, and sense of security. This provides strong base from which they develop self identity, self respect, a sense of confidence and work. The Government and Non Government Institutions, Social Scientists should focus their attention to these children and families as they struggle to cope with this devastating disease. The present study suggests that the need for intervention targeting towards orphaned children to restore their optimum level of functioning and preventing them from maladjustment.

\section{CONCLUSIONS}

1. The orphan children with HIV/AIDS have a lower social, emotional and educational adjustment than non-orphan children with HIV/AIDS.

2. Girl and rural orphan children with HIV/AIDS have lower social and emotional adjustment than boy and urban orphan children with HIV/AIDS.

3. There is no gender difference in educational adjustment of orphan children with HIV/AIDS.

\section{REFERENCE}

Altman, L.K. (2002). U.N. forecasts big increase in AIDS death toll. The New York Times, A1, A6. In Shelly E. Taylor, Health psychology ( $6^{\text {th }}$ ed.) New Delhi: Tata McGraw-Hill publishing company limited.

Armistead, L., \& Forehand, R. (1995). For whom the bell tolls: Parenting decisions and challenges faced by mothers who are HIV seropositive. Clinical Psychology: Science and Practice, 2, 239-250.

Atwine, B., Cantor-Graae, E., and Bajunirwe, F. (2005). Psychological distress among AIDS orphans in rural Uganda. Social Science and Medicine, 61(3): 555-564.

Baggaley, R.C., Needham, D. (1997). Africa’s emerging AIDS - orphans crisis. Canadian Medical Association Journal.

Baguma, P., Muhanguzi, F.K. (2000). Gender inequalities in education, Education policy and Budget. In Mukama, R. (Ed.), The Gender Budget 1998/99. Kampala, Uganda: Forum for Women in Democracy (FOWODE).

Beck, A., Ward, C., Mendelson. M, Mock J., and Erbaugh, J. (1961). An inventory for measuring depression. Archives of General Psychiatry, 4: 561-571.

Bhargava, A. (2005). The AIDS epidemic and the psychological well-being and school participation of Ethiopian orphans, Psychology, Health and Medicine, 10(3): 263-275. 


\section{Psychosocial Adjustment among Orphan Children Living with HIV/AIDS}

Brown, L. K., Lourie, K. J., \& Pao, M. (2000). Children and adolescents living with HIV and AIDS: A review. Journal of Child Psychology and Psychiatry, 41, 81-96.

FAWE News, (2000). Girls? Empowerment. Let the Girls be Seen and Heard No. 8(1). http://www.fawe.org/contents/newslet81d.html. 3/2/01.

Gaughan, D. M., Hughes, M. D., Oleske, J. M., Malee, K., Gore, C. A., \& Nachman, S. (2004). Psychiatric hospitalizations among children and youths infected with human immunodeficiency virus infection. Pediatrics, 113, 544-551.

Huurre, T.M., Aro, H. M. (2002). Long-term psychosocial effects of persistent chronic illness. European child \& adolescent psychiatry: 11(2), 85-91.

KSAPS. (2010). Consolidated On ART Report- October-2010 Bangalore: Karnataka State Aids Prevention Society.

Lwin, R., \& Melvin, D. (2001). Annotation: Pediatric HIV infection. Journal of Child Psychology and Psychiatry, 42, 427-438.

Makame, V., Ani, C., and McGregor, S. (2002). Psychological well-being of orphans in Dar ElSalaam Tanzania. Acta Paediatrica, 91: 459-465.

Mellins, C. A., Smith, R., O’Driscoll, P., Magder, L. S., Brouwers, P., Chase, C. (2003). High rates of behavioral problems in perinatally HIV-infected children are not linked to HIV disease. Pediatrics, 111, 384-393.

Miller, J. J. (1993). Psychosocial factors related to rheumatic diseases in childhood. Journal of Rheumatology, 20, 1-11.

Monroe, P. (1990). International encyclopedia of education, New Delhi: Cosmo Publications.

NACO (2009-10). Annual report -2009-10. New Delhi: National AIDS Control Organization, Ministry of Health and Family Welfare, Govt. of India.

Tate, D., Paul, R.H., Flanigan, T.P., Tashima, K., Nash, J., Adair, C., Boland, R., Cohen, R.A. (2003). The impact of Apathy and Depression on Quality of Life in Patients Infected with HIV/ AIDS. Patient Care and STDs: 17 (3).

Uganda Bureau of Statistics. (2006). Population and Housing Census-2006. Uganda Bureau of Statistics Publication. Kampala, Uganda: Ministry of Finance.

UNICEF (2004). Children on the brink 2004: A joint report of new orphans estimates and a framework for action. Geneva:UNIADS.

Veit-Wilson, J. (1998). Setting Adequacy Standards. Bristol: Polity Press.

Wachsler-Felder, J. L., Golden, C. J. (2002). Neuropsychological consequences of HIV in children: A review of current literature. Clinical Psychology Review, 22, 441-462.

Wahl, K.H., Blackhurst, A. (2001). Factors affecting the Occupational and Educational Aspirations of Children and Adolescents. Professional School Counseling, 3, 5.

Yun Dai, D. (2001). A Comparison of Gender Differences in Academic Self-Concept and Motivation between High -Ability. Journal of Secondary Gifted Education, 13, 1. 